\title{
An examination of forest cover change at Angkor, Cambodia, using satellite imagery, interviews and interpretation of historical events
}

\author{
Nathan A. Wales \\ School of Geography, Earth Science \& Environment, Faculty of Science, Technology \& Environment The University of the South Pacific, Laucala Campus, Suva, Fiji
}

\section{A R T I C L E I N F O}

\section{Keywords:}

Southeast Asia

Multiple method

Image classification

Forest

Resource governance

Livelihood

\begin{abstract}
A B S T R A C T
In the three decades since the mid-1970s through to the early 2000s forest cover at the Angkor World Heritage Site, Cambodia has not progressed linearly but in response to different historical events. This research uses multiple methods in comparing satellite image classification with key informant interviews and other forms of data at the landscape scale and at case studies to provide an historical perspective on forest cover change. The earliest date corresponds to the beginning of the civil war in Cambodia through to a time when a number of events had contributed to significant change in forest pattern and extent at Angkor. The change observed is a result of regulatory controls on land use, ongoing subsistence resource use activities and other events and processes, and more broadly reflects a country in transition and a history of conflict relating to resource governance. The research demonstrates that multiple methods combining medium resolution satellite imagery with interview data and processes detectable at specific time periods can be used to understand patterns of forest change and establish links to processes on the ground.
\end{abstract}

\section{Introduction}

There is no scarcity of research examining the relationship between patterns of land use and land cover (LULC) and influencing processes (Bürgi et al., 2004; Cassidy et al., 2010; Kong et al., 2019; Plieninger et al., 2015; Seto et al., 2002). However, the complexity of such relationships, including the variability observed at different spatial and temporal scales is often less well understood. With this in mind, this research uses multiple methods to untangle some of these relationships, more specifically the interaction between forest cover, livelihoods and regulatory controls, while presenting an historical perspective on the spatial pattern and extent of forest cover change at the Angkor World Heritage Site ("Angkor"), Cambodia (Fig. 1). Classified Landsat satellite imagery and interview data is used to examine forest cover change and events and practices linked to observed change at local scales.

As a mapping exercise this research brings together data from a number of sources and time periods in unravelling landscape and localscale processes of forest cover change at Angkor. The premise of Cambodia as a country in transition is presented followed by a review of existing research quantifying the relationship between remote sensing derived forest-change and influencing processes. Contextualisation of the study site is provided, including a brief history of land management, land use and forest survey and mapping at Angkor. The link between historical changes in forest cover and the events and practices associated with these changes are then considered by examining case studies. Lastly, reflections on the links between historical events and forest cover change, and the contribution of this research to the existing body of knowledge are provided in the conclusion.

\section{Background}

In Cambodia, forests provide essential livelihood, economic and ecological opportunities, and play an important role in a political and economic landscape that is often unregulated and unaccountable (Le Billon, 2000). Since the mid-1970s forest cover at Angkor has changed as a result of events such as instability caused by civil war, increased access to forest resources by the Vietnamese-sponsored government in the 1970s and 1980s and by the Cambodian military, World Heritage management regulation, national land and forest laws, and the direct and indirect impacts of tourism. For many, Cambodian forests represent places of conflict, have provided a refuge during times of conflict and have been important for financing conflict (Le Billon, 1999; 2001; 2002). Forests played a part in fuelling the Khmer Rouge ${ }^{1}$ conflict, and during the 1990s forests nearby and north-west of Angkor that were

E-mail address: nathan.wales@usp.ac.fj.

1 The extremist reform party, the 'Khmer Rouge', seized power in Cambodia in 1975. 
controlled by the Khmer Rouge were harvested, with the sale of most of this as timber to Thailand (Kiernan, 2007). Although Cambodia experienced improved economic and political opportunities in the 1990s forest area declined significantly over this period, and of the income generated from forests only small amounts were received by the public treasury and the people of Cambodia (Le Billon, 2002).

Inadequate measures for forest protection and management throughout Cambodia has raised questions about resource governance in the country given that forest management is a central item of good governance for the international community (Le Billon, 2002; Milne \& Mahanty, 2015). Political and economic transformation and instability, and the link between this, resource governance and forest change has been discussed by political ecologists such as Milne \& Mahanty (2015) and Le Billon (1999, 2000). Gururani and Vandergeest (2014) describe this transformation or changing landscapes as new frontiers in a post-conflict environment. Forests in Cambodia were a key part of the transition from war to peace, acting as a politicized resource that contributed to the construction of political power which was often outside formal governance (Le Billon, 1999; 2000). With the changing relationship between nature and society in contemporary Cambodia (Milne \& Mahanty, 2015) indeed one of the key tenets of the current research is that forest cover change in Cambodia can only be understood by appreciating the social and environmental dimensions of change, one which Milne \& Mahanty (2015) accurately describe as dynamic, interlinked, multi-scalar and power laden.

A cornerstone of the current study is an understanding of forest cover change at locations containing differing and often unclear land use regulation and management over long time periods and at variable spatial scales. In light of this, a review of the current state of research the site under study. With an archive of data supporting long temporal studies, classification of Landsat imagery in LULC studies has for many years yielded good results (Cassidy et al., 2013; Fox \& Vogler, 2005; Kong et al., 2019; Malila et al., 1984; Negassa et al., 2020). Cross-sensor change can improve the temporality of the research, as demonstrated by Fox and Vogler (2005), Kong et al. (2019) and Yismaw et al. (2014). Research by Haque and Basak (2017), Kong et al. (2019), Negassa et al. (2020) and Yismaw et al. (2014) demonstrates that the inclusion of socio-economic data, such as decision-making related to forest management can improve understanding of the changes identified from the remote sensing. In addition, an understanding of the processes influencing forest cover change cross-boundary and in protected area management using remote sensing are discussed by Fox and Vogler (2005) and Negassa et al. (2020).

With a breadth of approaches such as multi-sensor and multitemporal remote sensing classification, and the inclusion of socioeconomic survey data analysis, the value of combining multiple methods is demonstrated. However, the choice of methods is dependent upon the study site setting. Analysis at varying scales of geography to identify differences within the study site is emphasised in the current research, differences which can be explained by the timing of historical events such as the introduction of laws and regulations across different jurisdictional scales. And as discussed by Fox and Vogler (2005) and Negassa et al. (2020), being in a protected area requires understanding processes influencing cross-boundary (both physical and administrative) spatial and temporal change.

\section{Study site context}

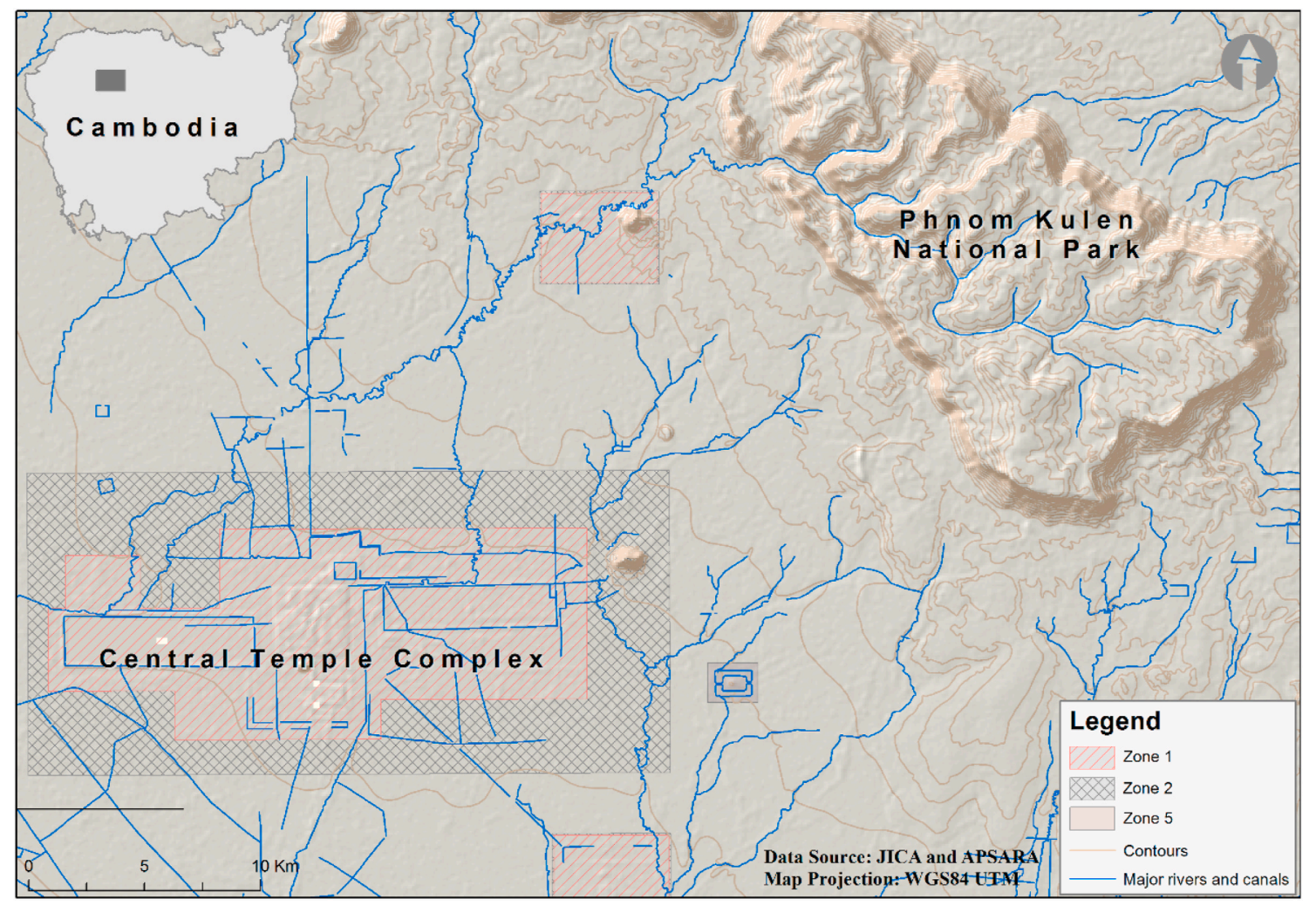

Fig. 1. Map of the Angkor study site including ZEMP Zones 1, 2 and 5 and Phnom Kulen National Park.

quantifying the relationship between remote sensing derived forestchange and influencing processes is presented.

A variety of approaches to understanding landscape interactions using remote sensing have been adopted, many of which are unique to
Angkor is located in the north-west of Cambodia in Siem Reap province (Fig. 1). For this study a twenty five year period from the mid1970 s to early 2000s is examined. This period was chosen because it represents a time of rapid socio-economic change which altered forests 
and traditional forest management practices at Angkor: the earliest date corresponds to the beginning of the civil war in Cambodia through to a time when a number of events had contributed to significant change in forest cover (Table 1). Observed change coincides with the timing of regulatory controls on land use and other events and processes.

\subsection{Forest mapping at Angkor}

At the latest date of the current research there was scarce published forest mapping research at Angkor, with few involving field surveys. Dy Phon's (2000) comprehensive study of the forest plants of Cambodia included extensive field research at Angkor, Rollet (1972) documented the forest types of Cambodia, while Legris and Blasco (1972) describe the influence of human activities on the forests of Cambodia. Forest surveys were conducted on the plateau of Phnom Kulen by Eav (1970) and forest mapping by Boulbet (1979) documents the most comprehensive survey of forest at Angkor. Ashwell and Fitzwilliams (1993) describe the vegetation ecology of Angkor, and Gaughan et al. (2009) used multi-temporal Landsat imagery to map forest conversion and quantify land cover change near Angkor. More recently Singh et al. (2015) mapped tree species at Angkor and Davies et al. (2016) mapped vegetation change near Angkor, both studies using image classification techniques.

\subsection{Land management at Angkor}

Management of Angkor is overseen by the United Nations Educational, Scientific and Cultural Organisation (UNESCO) and the Authority for the Protection and Management of Angkor and the Region of Siem Reap (APSARA) has directly managed the site since its 1992 World Heritage listing. The requirement for monitoring and management was an important condition of listing (Lemaistre \& Cavalier, 2002; Wager, 1995). Angkor contains five zones of management (Fig. 1).

Providing different levels of protection, these zones were established with the formulation of a Zoning and Environmental Management Plan (ZEMP) in 1994, with land use controls applied to each zone (Royal Government of Cambodia, 1994). Zones 1 and 2 were granted the highest level of protection while Zone 5, significantly larger in area, includes Phnom Kulen National Park ("Phnom Kulen") to the north-east and the Angkor plain between it and the central temple complex (UNESCO, 1994). The nature of Zones 3 and 4, making up only a small area and located predominantly along linear drainage channels, meant they could not be accurately examined in terms of forest area and as such were excluded from this study.

Table 1

Historical events and regulations.

\begin{tabular}{ll}
\hline Key event & Time period \\
\hline Khmer Rouge (civil war) & $1975-1979$ \\
World Heritage listing & 1992 \\
Zoning and Environmental Management Plan (ZEMP) and the Royal & 1994 \\
$\quad \begin{array}{l}\text { Decree Establishing Protected Cultural Zones in the Siem Reap/Angkor } \\
\quad \text { Region and Guidelines for their Management }\end{array}$ & \\
Controls on forest clearing introduced by the management authority & 2000 \\
$\quad$ APSARA & \\
Other event & Time \\
& period \\
Pro-Vietnamese Government (PRK) in Cambodia & 1989 \\
United Nations Transitional Authority in Cambodia (UNTAC) & 1992 \\
$\quad$ established to oversee Government administration and & \\
$\quad$ peacekeeping & \\
Land Law introduced & 1992 \\
National Park designation of Phnom Kulen & 1993 \\
Land Law revisited & 2001 \\
Law on Forestry & 2002 \\
\hline
\end{tabular}

\subsection{Forests, livelihoods and land use history}

Angkor is a geographical palimpsest reflecting a highly modified landscape, and as a testament to the ongoing interaction of local people with the landscape it provides insight on the influence of past human settlement. Extensive landscape modification including deforestation occurred during the Angkorian period of the Khmer Empire (9th-15th century) (Evans et al., 2007), with lowland forests replaced by rice growing (Hagesteijn, 1987). During the 1970s and early 1980s forest vegetation near the central temple complex established largely unhindered (Freeman, 2004, Fig. 1). After 1980, and coinciding with the end of the Khmer Rouge era, forest flora within the central temple complex of Angkor was generally in poor condition (Ashwell \& Fitzwilliams, 1993), and at the time of Angkor's 1992 listing this was the only location where dense evergreen and semi-evergreen forest was preserved (UNESCO, 1994). Swidden agriculture, typically non-permanent, was the main form of forest encroachment on the plateau of Phnom Kulen (Ashwell \& Fitzwilliams, 1993).

Despite centuries of ongoing dependence by local people on forests for livelihoods (Giteau (1976; Legris \& Blasco, 1972), exclusionary policies associated with Angkor's listing resulted in conflict over available forest resources as forest access became increasingly regulated (Le Billon, 2000). Patches of secondary forest and shrubland vegetation, which commonly occur as islands surrounded by rice fields at Angkor continued to be used by local people for firewood and other non-timber forest products (NTFPs) (Ashwell \& Fitzwilliams, 1993). At the latest date of the current research NTFPs made up a significant portion of local forest resources in Cambodia (ITTO, 2005), with approximately $92 \%$ of the rural population dependent on forest-derived fuelwood to meet daily energy needs (Kim Phat et al., 2001). Despite this resource dependence local livelihoods became increasingly threatened with the progression of what Peluso and Lund (2011) describe as 'new frontiers of land control', with power rescinded from those most vulnerable who rely on subsistence activities to support livelihoods. The 1992 listing challenged the Cambodian Government's ability to ensure fair and equitable use and allocation of land at Angkor given the competing interests of tourism and development, and the already complex national land administration system was compounded by the World Heritage listing (Gillespie, 2009), resulting in considerable modification to the laws regulating and controlling land title and use, in addition to the creation of new laws.

\section{Key historical events}

This section summarises the historical events that have contributed to forest cover change at Angkor from the mid-1970s through the early 2000s. These events have occurred during the period of Cambodia's transition from war to peace, a time associated with instability and resource governance challenges, as discussed by Milne \& Mahanty (2015) and Le Billon (1999, 2000). The events that have had the greatest impact on the forests of Angkor, during the timeframe of the current research, include the 1992 World Heritage listing and management plan (ZEMP) that followed, and the introduction of controls on forest clearing by the management authority APSARA in the year 2000 (Table 1). In addition, the Khmer Rouge occupation from the mid-1970s to early 1980 s resulted in forest fragmentation as new strategies for land use and ownership were implemented (Kiernan, 2007). From the late 1970s to late 1980s the Vietnamese-sponsored government, the People's Republic of Kampuchea (PRK) impacted forests near Angkor (Hughes, 2009). Largely unregulated access to forest land at Angkor by the Cambodian military since the 1970s has also impacted upon forest cover and villagers' access to these resources (Le Billon, 2000, 2002), as have more recent regulations including the Land Law (Royal Government of Cambodia, 2001) and Law on Forestry (Royal Government of Cambodia, 2002).

Some of the events described in Table 1 fit neatly into the time periods of this research while others are less able to be tied to specific time 
periods. It is acknowledged that when interpreting forest change from the classified imagery, the delayed response (or lag time) to such events, as observable in the landscape will vary. While the focus of this research is on those "key events" listed in Table 1, the "other events" are acknowledged as these would have impacted on forest cover, perhaps more indirectly and in a way that is difficult to quantify from the methods used in this research.

\section{Methods}

This study uses NASA Landsat images acquired from the Landsat Multispectral Scanner System (MSS), Landsat Thematic Mapper (TM) and Landsat Enhanced Thematic Mapper (ETM+) satellite sensors (Table 2). Spatial data differentiating forest from non-forest was created from the Landsat images for the years 1976, 1990, 1995 and 2002 using maximum likelihood supervised image classification (Foody \& Arora, 1996; Kahya et al., 2008; Richards \& Jia, 2013) (Table 2; Fig. 2). All images were single date, cloud-free and near-anniversary to ensure seasonal differences did not impact on accurate comparability of the classified imagery. Forest/non-forest area maps and statistics were calculated across the full extent of the four images (Fig. 2) and at three case studies (Fig. 3).

400 random point locations were generated using ArcGIS ${ }^{\circledR}$ software by ESRI ${ }^{\mathrm{TM}}$ across the full extent of the imagery. From the set of random points, those identified as forest during field survey between February 2007 and April 2009 were recorded as XY locations using a Trimble ${ }^{\mathrm{TM}}$ Juno handheld GPS unit. From the total number of random points 70 were assessed as forest and used in image classification and validation.

To address the limitation of temporally aligning dates of field survey with image dates, survey sites were not used in the classifications where it was determined during fieldwork that significant disturbance or forest loss had occurred at the site since the date of the earliest (1976) image. All points were differentially corrected using base station data, improving the positional accuracy to less than $2 \mathrm{~m}$ after correction. Areas of similar spectra were identified from each Landsat image using ENVI ${ }^{\circledR}$ software and, with the forest survey sites, used to create training sites for image classification. Sites assessed as non-forest during fieldwork were not included in the classification.

\subsection{Forest definitions for classification}

Efforts to quantify forest area and extent from the local to the global scale have frequently used the Food and Agriculture Organisation of the United Nations (FAO) definition of forest (FAO, 2000; Redmond et al., 2016; Stibig et al., 2004). Despite its criticisms (Colson et al., 2009; Fairhead \& Leach, 1998; MacDicken, 2015; Sloan \& Sayer, 2015) the definition has remained consistent and therefore temporally reliable since 2000 (MacDicken, 2015). Defining forest as patches of woody vegetation larger than 0.5 ha in size, the FAO definition is appropriate to this research. The definition also describes trees higher than $5 \mathrm{~m}$, canopy cover of more than 10 percent, and excludes land that is predominantly under agricultural or urban land use. Attributes that were used in defining forest during field data collection included those contained in the FAO definition plus: forest cover density, height, and species composition and dominance (Chazdon et al., 2016; Rundel, 1999;
Zimmermann \& Clements, 2004). All species identified were cross-checked against the plant descriptions described by Dy Phon (2000). Only those locations where all of these attributes were identified were included as forest points for classification.

\subsection{Image pre-processing, classification and validation}

Prior to classification all images were overlaid and co-registered to ensure that each shared the same spatial extent. This was not done for the Landsat MSS (1976) image due to the different spatial resolution of the image compared with the TM and ETM + images. All images were classified using only those bands common to each image (Table 2). Bands 1-3 (green, red and near-infrared respectively) of the Landsat MSS (1976) image were used as they are the most closely aligned in wavelength to bands 2-4 of the Landsat TM (1995) and Landsat (ETM+) 2002 images (Table 2). The blue band (band 1) of the TM and ETM + images was excluded as there is no corresponding wavelength in the MSS image and given the problem of atmospheric scattering in the shorter wavelengths which typically adds artificial brightness (Hadjimitsis et al., 2010). Atmospheric correction, normally done to reduce differences caused by atmospheric or sensor variation between images was not necessary given the blue band was excluded, the images were cloud-free and because the current research involves classifying multiple images individually then comparing them to identify change (Foody et al., 1996 and Song et al., 2001). The image classification outputs are presented in the discussion (Fig. 2) and at case studies.

An assessment of accuracy was completed to validate the classified images (Foody, 2002). Forest survey points were partitioned into training (mapping) and verification (reference) datasets. All reference points that were not used in the classification were overlaid with each classification in a GIS to examine the frequency at which each point coincided with the area of forest defined in each classification. Of the 70 field forest surveys points 29 were used to assess the accuracy of the classified images. While the number of points used in accuracy testing was smaller than the recommended "rule of thumb" of 50 per class (Congalton, 1991; Lillesand et al., 2015) it was felt to be justified given the classification accuracies achieved; the within-class variation was well accounted for because the classification and testing comprised a single class (forest); and given that a similar number of points has been used successfully by authors such as Rogan et al. (2002) who used 30 points per class to test Landsat image classifications. In addition, it was expected that based on established research the 400 random points generated for field survey would deliver an adequate number of forest survey points, however as few as one in six (17.5\%) of these points were assessed as forest. Time and resource constraints did not allow for further field data collection. Classification accuracy of the four images was $86.2 \%$ (1976), 80.6\% (1990), 83.3\% (1995) and 90.2\% (2002), all acceptable accuracies based on existing research (Congalton, 1991; Thapa \& Murayama, 2009).

The highly fragmented nature of forest across the study site, including forest areas often less than 0.1 ha proved a challenge to classification. In addition, small errors in image registration and image resolution may have compromised the results of the accuracy assessment. Existing research describing the spectral patterns of known substrates (Curran, 1985; Lillesand et al., 2015) and visual inspection of

Table 2

Corresponding bands of Landsat MSS, TM and ETM + used in classifying forest.

\begin{tabular}{|c|c|c|c|c|c|c|c|c|}
\hline \multirow[b]{2}{*}{ Band } & \multicolumn{3}{|c|}{ Landsat MSS (January 16, 1976) } & \multicolumn{3}{|c|}{$\begin{array}{l}\text { Landsat TM (November 17, 1990; } \\
\text { January } 31,1995 \text { ) }\end{array}$} & \multicolumn{2}{|c|}{ Landsat ETM+ (January 10, 2002) } \\
\hline & Spectral Bands $(\mu \mathrm{m})$ & Spatial Resolution & Band & $\begin{array}{l}\text { Spectral } \\
\text { Bands }(\mu \mathrm{m})\end{array}$ & Spatial Resolution & Band & $\begin{array}{l}\text { Spectral } \\
\text { Bands }(\mu \mathrm{m})\end{array}$ & $\begin{array}{l}\text { Spatial } \\
\text { Resolution }\end{array}$ \\
\hline 1 & $0.50-0.60$ & $57 \mathrm{~m} /$ pixel & 2 & $0.525-0.60$ & $30 \mathrm{~m} /$ pixel & 2 & $0.525-0.605$ & $30 \mathrm{~m} /$ pixel \\
\hline 2 & $0.60-0.70$ & $57 \mathrm{~m} /$ pixel & 3 & $0.63-0.69$ & $30 \mathrm{~m} /$ pixel & 3 & $0.63-0.69$ & $30 \mathrm{~m} /$ pixel \\
\hline 3 & $0.70-0.80$ & $57 \mathrm{~m} /$ pixel & 4 & $0.76-0.90$ & $30 \mathrm{~m} /$ pixel & 4 & $0.75-0.90$ & $30 \mathrm{~m} / \mathrm{pixel}$ \\
\hline
\end{tabular}




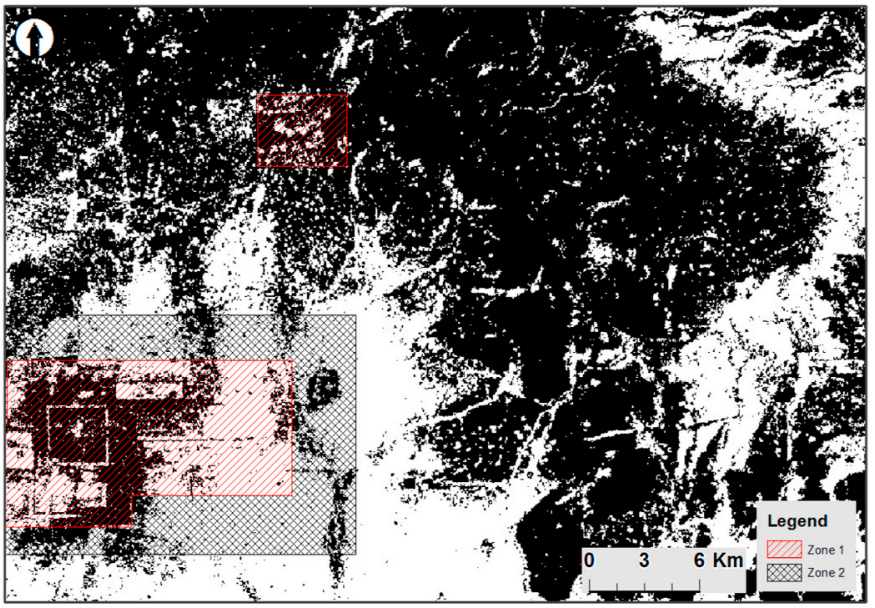

(a)

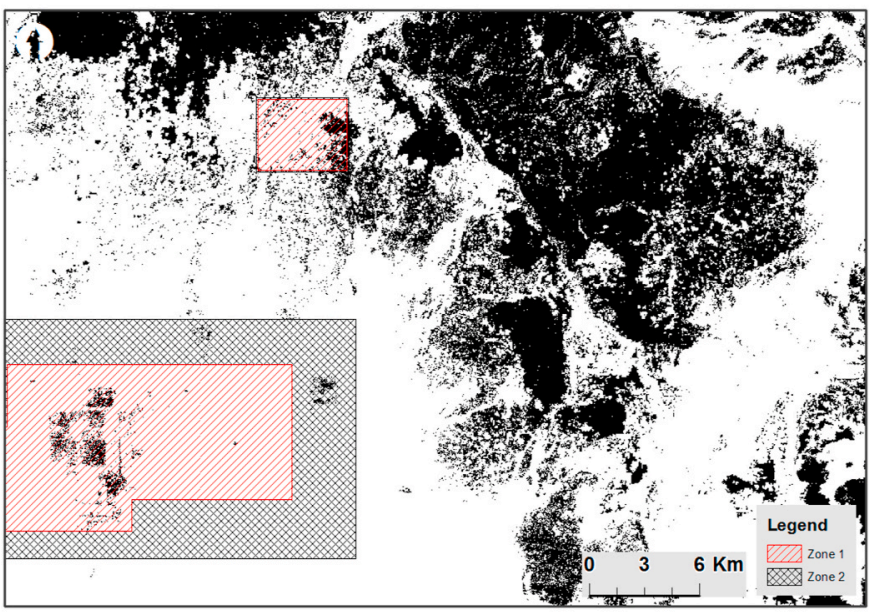

(c)

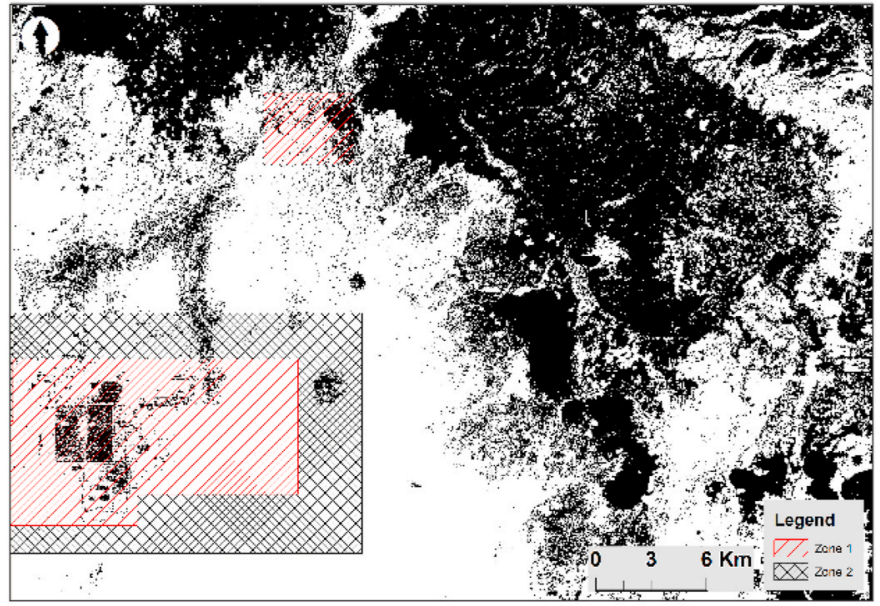

(b)

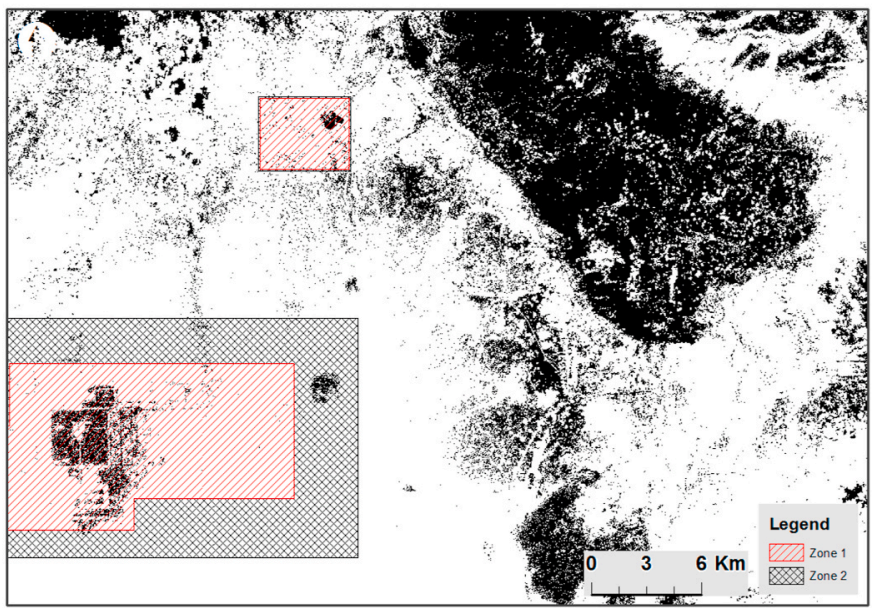

(d)

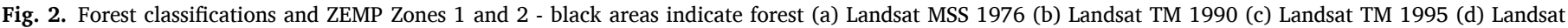
$\mathrm{ETM}+2002$.

spatially co-incident areas of forest/non-forest from a $10 \mathrm{~m}$ resolution 2004 SPOT 5 image provided a means to validate the classified imagery.

\subsection{Interviews}

Combining observations from interviews with quantitative image classification data is useful in geography research emphasising the relationship between physical and human processes (Cope \& Elwood, 2009; Fox et al., 2003; Jiang, 2003; Philip, 1998). Interviews with 18 key informants took place in Cambodia between July 2007 and June 2009. Identifying informants who were well versed in the research subject under investigation maximised the opportunity for gathering relevant information (Hay, 2005). Information garnered from interviews was used to gain a clearer understanding of the influence of historical events on the spatio-temporal patterns of forest cover. Interviews also gave insight into the connection between forests and subsistence livelihoods of local people. Broadly, the focus of questioning during interviews was on forest land use history, current land use strategies of local people living at the site, and forest management policy and regulations affecting Angkor. Information generated from the key informant interviews is discussed in light of remote sensing observations at case studies in the discussion.
Key informants interviewed included representatives from the Angkor management authority APSARA, Cambodian Ministry of Environment (MoE), Cambodian Forestry Administration (FA), United Nations Educational, Scientific Cultural Organisation (UNESCO), Regional Community Forestry Training Centre Bangkok (RECOFTC), Food and Agriculture Organisation of the United Nations (FAO), International Union for Conservation of Nature IUCN), Wildlife Conservation Society (WCS), Community Based Natural Resource Management Learning Institute (CBNRMLI), the Angkor Participatory Development Organisation (APDO) and regional ecologists. Interview questions and detailed responses are available from the author on request. For privacy reasons the names of individual informants has not been included. Maps were not presented to informants during interviews because as a representation of reality features on maps can often be misleading (Verplanke et al., 2016).

\section{Results and discussion}

This section begins by summarising some general observations before moving to more detailed case studies. 


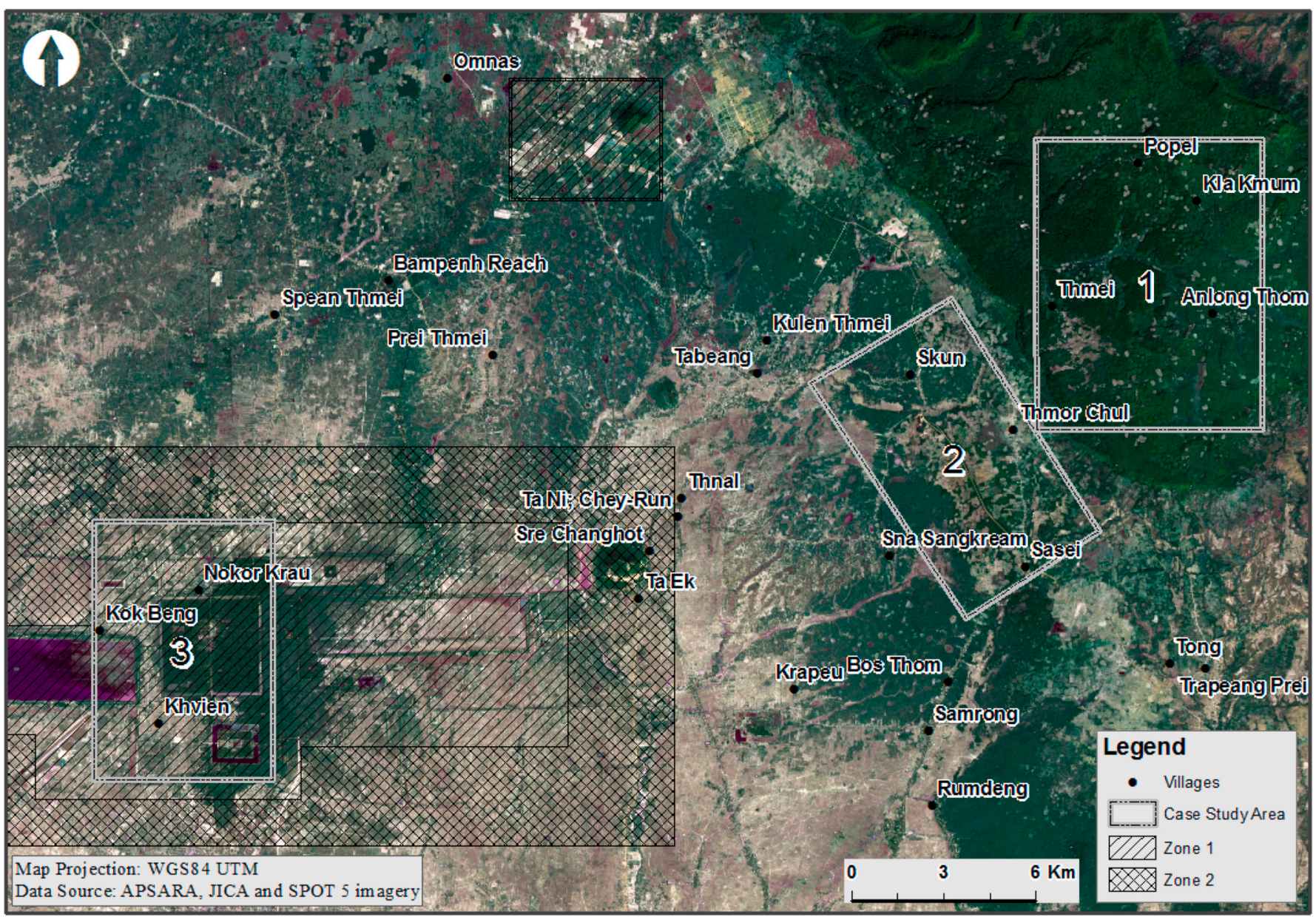

Fig. 3. Location of three case study areas (1-3), including ZEMP Zones 1 and 2, overlaid on a $10 \mathrm{~m}$ resolution 2004 SPOT image displayed in true colour. (For interpretation of the references to colour in this figure legend, the reader is referred to the Web version of this article.)

\subsection{General observations}

Forest cover at Angkor has varied both temporally and spatially, with historic events having acted upon the landscape differently. An examination of the forest/non-forest areas provides insight into the spatio-temporal patterns of forest cover in light of historic events (Table 3). While there was an overall decline in forest area between 1976 and 2002, there was also localised variation in the area and pattern

Table 3

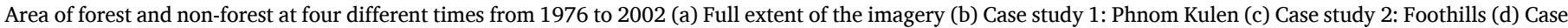
study 3: Central Temple Complex.

\begin{tabular}{|c|c|c|c|c|c|c|c|c|}
\hline \multirow[t]{2}{*}{ Land cover type } & \multicolumn{2}{|c|}{ Landsat MSS 1976} & \multicolumn{2}{|c|}{ Landsat TM 1990} & \multicolumn{2}{|c|}{ Landsat TM 1995} & \multicolumn{2}{|c|}{ Landsat ETM+ 2002} \\
\hline & Area (ha) & $(\%)$ & Area (ha) & $(\%)$ & Area (ha) & $(\%)$ & Area (ha) & $(\%)$ \\
\hline Forest & 102,912 & 60 & 69,165 & 41 & 50,070 & 29 & 41,618 & 24 \\
\hline Non-forest & 67,992 & 40 & 101,502 & 59 & 120,597 & 71 & 129,050 & 76 \\
\hline \multirow[t]{2}{*}{ Land cover type } & \multicolumn{2}{|c|}{ Landsat MSS 1976} & \multicolumn{2}{|c|}{ Landsat TM 1990} & \multicolumn{2}{|c|}{ Landsat TM 1995} & \multicolumn{2}{|c|}{ Landsat ETM+ 2002} \\
\hline & Area (ha) & $(\%)$ & Area (ha) & $(\%)$ & Area (ha) & $(\%)$ & Area (ha) & $(\%)$ \\
\hline Forest & 6342 & 92 & 5853 & 84 & 5539 & 80 & 5709 & 82 \\
\hline Non-forest & 586 & 8 & 1105 & 16 & 1419 & 20 & 1248 & 18 \\
\hline \multirow[t]{2}{*}{ Land cover type } & \multicolumn{2}{|c|}{ Landsat MSS 1976} & \multicolumn{2}{|c|}{ Landsat TM 1990} & \multicolumn{2}{|c|}{ Landsat TM 1995} & \multicolumn{2}{|c|}{ Landsat ETM+ 2002} \\
\hline & Area (ha) & $(\%)$ & Area (ha) & $(\%)$ & Area (ha) & $(\%)$ & Area (ha) & $(\%)$ \\
\hline Forest & 4193 & 88 & 3565 & 75 & 3008 & 63 & 1517 & 32 \\
\hline Non-forest & 584 & 12 & 1211 & 25 & 1768 & 37 & 3258 & 68 \\
\hline \multirow[t]{2}{*}{ Land cover type } & \multicolumn{2}{|c|}{ Landsat MSS 1976} & \multicolumn{2}{|c|}{ Landsat TM 1990} & \multicolumn{2}{|c|}{ Landsat TM 1995} & \multicolumn{2}{|c|}{ Landsat ETM+ 2002} \\
\hline & Area (ha) & $(\%)$ & Area (ha) & $(\%)$ & Area (ha) & $(\%)$ & Area (ha) & $(\%)$ \\
\hline Forest & 3016 & 62 & 1016 & 21 & 449 & 9 & 962 & 20 \\
\hline Non-forest & 1855 & 38 & 3855 & 79 & 4423 & 91 & 3909 & 80 \\
\hline
\end{tabular}

All tables by the author. 
of forest at each date. Additionally, the extent of forest conversion on the plateau of Phnom Kulen to the north-east of the study site, across all time periods, was significantly less than on the Angkor plain, nearer the centre of each image (Fig. 1; Fig. 2). This observation is in-part due to the nature of swidden agriculture, common on the plateau and frequently not well detected using coarse resolution Landsat imagery. Much of the area classified as non-forest in 1976, notably on the Angkor plain and on the slopes immediately south-east of Phnom Kulen, likely indicates areas cleared for agriculture prior to that date. The extent and pattern of forest to non-forest for each time period is shown in Fig. 2.

The period from 1990 through to 2002 corresponds with a period in which regulatory changes affecting Angkor had considerable impact on forest cover. Distinct areas of forest cover change between these two dates are evident on the foothills and higher slopes in the north and north-east of the study site (Fig. 2). The extent of forest cover in the less regulated area leading to the foothills (from the centre of each image in Fig. 2) and plateau of Phnom Kulen was relatively stable between 1990 and 1995. This is in contrast to the extensive decline in forest cover at the same location between 1995 and 2002, which appear as large fragmented areas associated with permanent forest conversion, and perhaps a reflection of the 'new frontiers of land control' in a postconflict environment, as described by Chann (2009), Gururani and Vandergeest (2014), Milne and Mahanty (2015) and Peluso and Lund (2011). Although some areas of the Angkor plain including locations near the foothills of Phnom Kulen experienced forest loss between 1990 and 1995, large fragmented patches remained (Fig. 1; Fig. 2). By 2002 large areas of the landscape on the Angkor plain had been converted to non-forest land.

Between 1976 and 2002 virtually all forest had disappeared from the area immediately surrounding the smaller northern sector of Zone 1 (Fig. 2). However, the most considerable decline in forest at this location occurred between 1976 and 1990, the period prior to introduction of the ZEMP. Observation from the literature (Hughes, 2009) and key informant interviews suggests that forest decline in this area was likely due to the activities of the Khmer Rouge and the Vietnamese sponsored Cambodia government throughout the 1980s. The area experienced some further loss of forest between 1990 and 2002; this was despite the regulations introduced following implementation of the ZEMP.

\subsection{Case studies}

Despite an overall decrease in the area of forest being observed across the entire study site, the pattern of forest change and proportion of forest compared to non-forest varies when examined at case studies (Fig. 3; Table 3). This is due in-part to the influence of the different management zones. For example, case study 3 (Zone 1) shows an increase in the area of forest between 1995 and 2002 while case study 2 (Zone 5) shows a notable decrease in the area of forest for the same period (Table 3 ).

\subsubsection{Case study 1: Phnom Kulen}

Phnom Kulen, located on the plateau north-east of the central temple complex is unique as it is designated as a Cambodian National Park yet also comes under World Heritage management (Fig. 1; Fig. 3). The site contains a small residential population and large area of forest when compared with the other case studies. It is also part of an important watershed supplying water for agriculture before draining into the Tonlé Sap (Kummu, 2009). According to one key informant, insecure management means controls on forest access and use are less stringently enforced at this location compared to elsewhere at Angkor, due in-part to its relative isolation, and the lack of transparency of existing management strategies. In the 1990s this 'insecurity' characterising forested areas in Siem Reap province according to Le Billon (1999) supported armed and often violent groups with logging interests who relied on the sale of forest timber to support their survival.

General stability in the area of forest cover was observed in Phnom
Kulen between 1990 and 2002 (Table 3b). This in-part reflects the restrictions on forest access imposed on villagers and other forest users with the introduction of the ZEMP and National Park designation during this time. In addition, some areas designated as community forests located here offered additional forest protections (Hubbard, 2002; Wager, 1995). Between 1976 and 2002 the area of forest at this case study decreased by approximately $10 \%$, with the majority of this decrease between 1976 and 1990 (Fig. 4; Table 3b). More notable then the change in area of forest was change in the pattern of forest cover within the case study, with increasing amounts of forest fragmentation occurring (Fig. 4). Field observations and multiple key informants indicated that despite long periods of ongoing human-induced disturbance, an increase in the frequency and intensity of this disturbance since the late 1980s and through the 1990s has resulted in a decline in the quality and composition of remaining forests at the site. While the reason for this is unclear, it does coincide with the period when military forces were issued forestry concessions within Phnom Kulen by the Cambodian Government (Le Billon, 1999). An associated increase in patchwork larger scale logging may help to explain the fragmented pattern observed.

As confirmed from field observations forest in this area corresponds with what Boulbet, 1975 describes as scattered areas of low open forest, exposed sandstone and grasslands (Fig. 5).

\subsubsection{Case study 2: foothills}

Case study 2, located at the foothills of Phnom Kulen in ZEMP Zone 5 (Fig. 3) showed a 13\% decline in the area of forest between 1976 and 1990 , the period shortly before World Heritage listing. This compares to an $8 \%$ decline during the same period in case study 1 (Table 3 ). This case study experienced the largest amount of forest loss, when compared with the other case studies. The most noteworthy loss occurred after 1995, coinciding with the introduction of the World Heritage zoning, through to 2002 (Fig. 6). Between 1976 and 2002 the area of forest at this case study decreased by more than $60 \%$, six times that which occurred in case study 1 for the same period (Table 3). By 2002 most of the forest in this case study, and in the neighbouring area on the southern and western foothills of Phnom Kulen, had been converted to other land uses. The decline in forest cover at this location was in-part associated with a shift in the concentration of forest resource use away from the increasingly regulated Zones 1 and 2, towards the less regulated Zone 5, within which this case study lies. This observation was well supported by those interview respondents who have engaged with this landscape over a long period of time, and who recognise the regulations associated with the ZEMP zoning to be a contributor to forest loss at locations further afield. Research by Kintz et al. (2006) in a protected area in the Andes similarly demonstrated that forest located inside a National Park was well maintained while forests located outside of park boundaries slowly became degraded.

The marked decline in the area of forest between 1990 and 2002, including an approximate 50\% reduction between 1995 and 2002 is supported by findings from key informant interviews which point to a rapid acceleration in forest clearing, and with it reduced availability of forest resources for local people during the mid-late 1990s. The sizeable reduction in forest cover observed from the mid-1990s to early 2000 s coincided with the restrictions on forest access imposed on villagers at this time in Zone 1 and 2, and may also reflect the restrictions associated with the formation of Phnom Kulen as a National Park in 1993. These restrictions appear to have had the effect of forcing local forest users outside of the more regulated National Park, and ZEMP Zones 1 and 2, into the foothills and Angkor plain in Zone 5, the area examined in this case study. Findings from more than one key informant interview indicated that during this time there had been an increase in ownership, access and use of forest land by outside operators (often larger commercial operators and others with land interests from Siem Reap province or Phnom Penh), resulting in a decrease in access to forests by local villagers. This affirms the argument of Le Billon's (2002) that the 


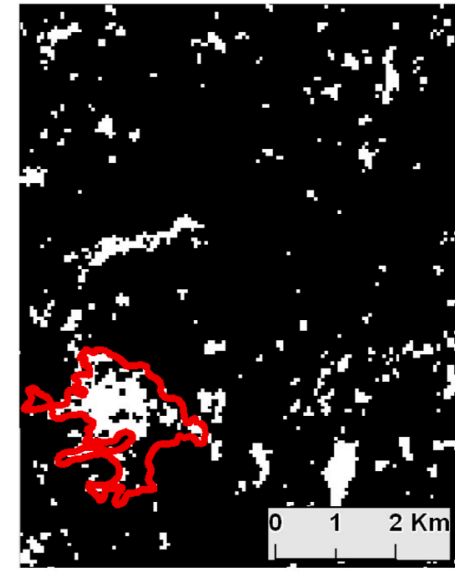

1976

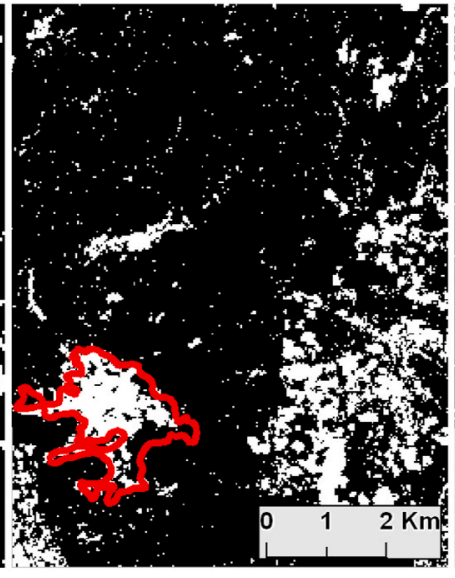

1990

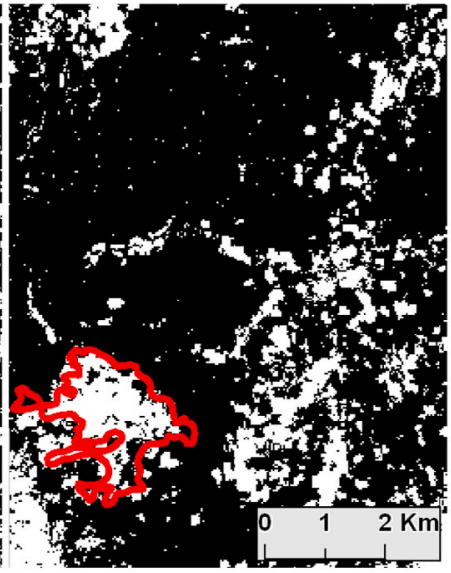

1995

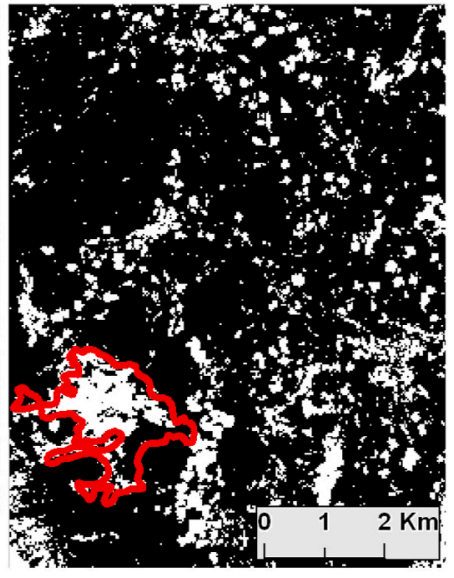

2002

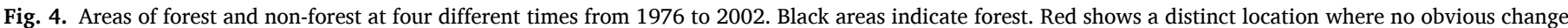
has occurred. (For interpretation of the references to colour in this figure legend, the reader is referred to the Web version of this article.)

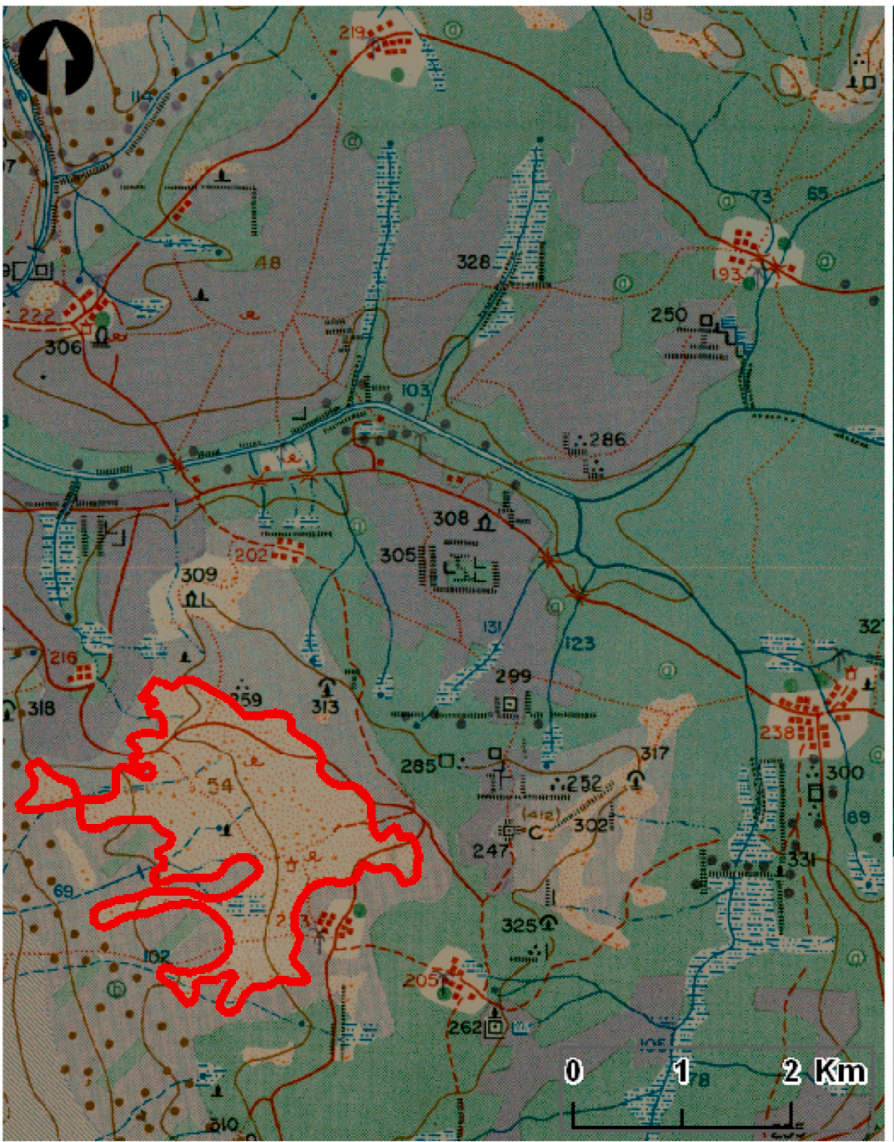

(a)

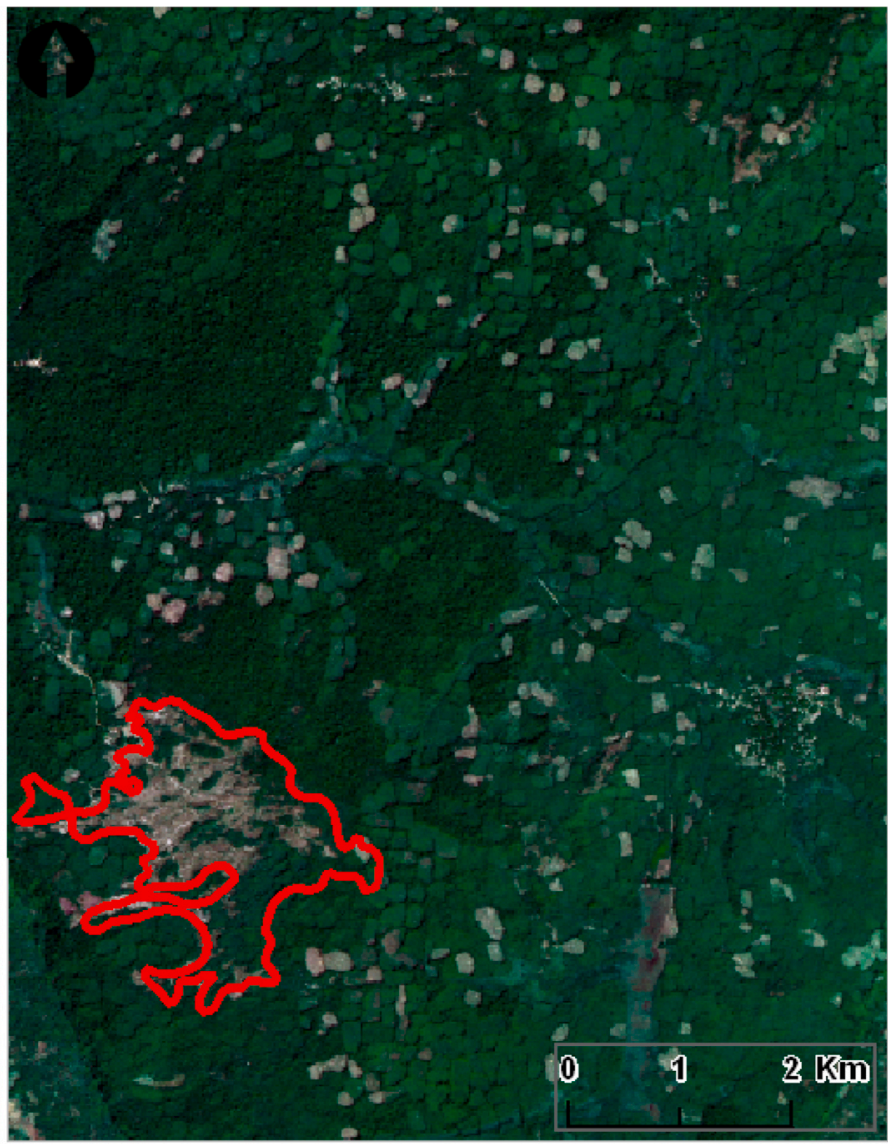

(b)

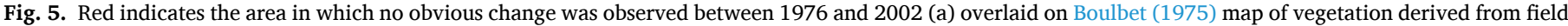

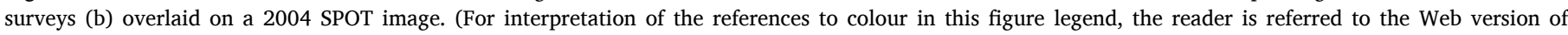
this article.)

increased regulation of forests in Cambodia throughout the 1990s occurred at the expense of the poor, and often led to a rise in illegal logging activities. While not proposing a causal link, this increased influence of larger operators also coincides with the increase in the spatial scale at which forests began to decline, as observed in this case study
(Fig. 6).

This case study corresponds spatially with important earlier forest mapping by Boulbet (1979) who describes a distinctive forest type 'Degraded Forests on Red Basalt Soils' (Forêts dégradées sur les sols de basalte rouge) only found at this location at Angkor. The area of this 


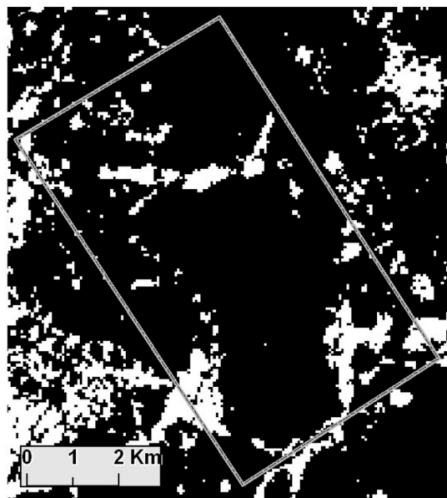

1976

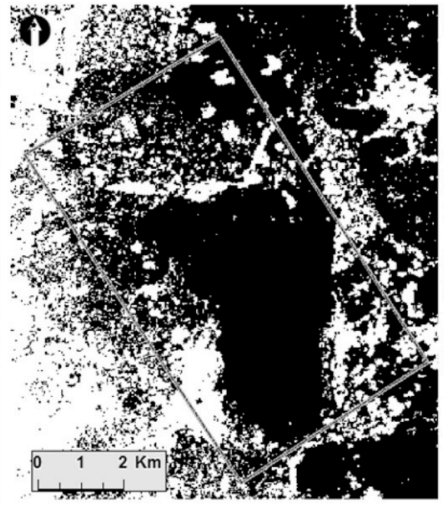

1990

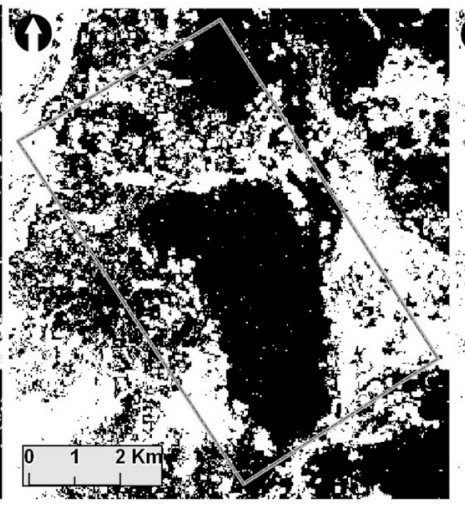

1995

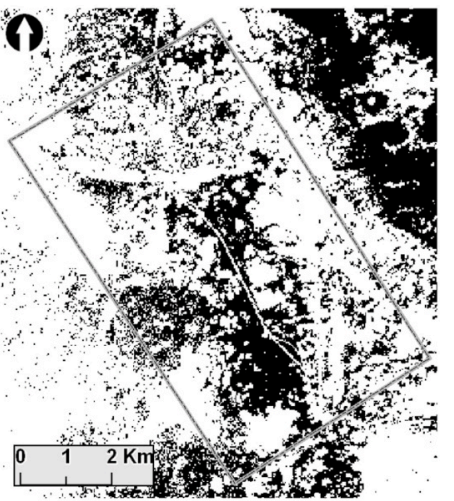

2002

Fig. 6. Areas of forest and non-forest at four different time periods from 1976 to 2002. Black areas indicate forest.

forest type can be seen by the clearly distinguishable feature in Figs. 6 and 7. Boulbet's description of this forest indicated that some species, such as Dipterocarpusalatus (Chhetiel), Heritierajavanica (Duengchaem) and Mesuaferrea (BohsNiek) had been targeted for clearing at an earlier but unknown time (Boulbet, 1975). ${ }^{2}$ Despite the extensive clearing of neighbouring forests, which began as early as the 1980s, it was not until the late 1990s or early 2000s that extensive clearing of this forest type occurred (Fig. 6).

\subsubsection{Case study 3: central temple complex}

Case study 3 is located entirely in Zone 1 where management controls on forest access and use have been strictly enforced since implementation of the ZEMP in 1994. This is in contrast to case study 1 and 2 which have less secure protective status. A large number of people live within, and interact with the landscape here on a daily basis. Forests located in this case study have experienced various cycles of change over centuries (Legris \& Blasco, 1972), and within the time period of this research. The largest area of forest in case study 3 is located in the walled city of Angkor Thom, established in the 12th century and identifiable by the obvious square in Fig. 8. These forests experienced considerable disturbance after the collapse of the Angkor civilization between the 16th and 17th century (Ashwell \& Fitzwilliams, 1993). Between 1976 and the early 1990s forest throughout Zone 1, with the exception of Angkor Thom, was in poor condition.

In 1976 more than $60 \%$ of the case study was forested, and by 1990 and 2002 this had fallen to $20 \%$, a three-fold decrease in forest cover at both time periods. Between 1990 and 1995 there was a 50\% decline in forest cover, with the majority of forest located outside of Angkor Thom removed. However, between 1995 and 2002 there is evidence of a 50\% increase in forest (Table 3; Fig. 8).

Forest loss has not been linear in this case study, unlike in case study 2. The events and regulations described in Table 1 have, to varying degrees, impacted forest access and use differently, particularly since the mid to late 1990s. The decline in the area of forest between 1990 and 1995 occurred prior to the ZEMP regulations having an impact on the ground, and prior to the controls on forest clearing introduced by the management authority APSARA in 2000. The increase in forest in the more recent period of this case study is likely a consequence of the controls on clearing introduced and enforced in Zones 1 and 2 by the management authority APSARA in the year 2000, and the lag effect of the World Heritage zoning regulations in the mid-1990s. This observation was repeatedly acknowledged during key informant interviews. According to a key informant from the management authority APSARA, the impact of the zoning on the extent of forest cover was not observable

\footnotetext{
${ }^{2}$ Khmer (Cambodian) names indicated in round brackets.
}

on the ground until at least the late-1990s.

There were few if any regulations controlling land use at Angkor prior to the ZEMP and this may explain the forest pattern observed in the first half of the 1990s. Notwithstanding the introduction of the strict controls associated with the ZEMP, findings from key informant interviews suggested that limited enforcement meant some local people continued using the forests within this case study, at that time, for small scale livelihood activities such as firewood collection, an observation supported by Le Billon (2002). After the mid-1990s access to forests and forest resources generally saw a decline, coinciding with an increase in the area of forest by 2002, the latest date of this research (Table 3; Fig. 8).

\section{Conclusion}

The review of the current state of research provided in the background offers advantages in using a multiplicity of approaches in unravelling the complexities of land cover change and influencing processes, which may include but are not limited to cross-sensor, multisensor and multi-temporal remote sensing analysis, effective integration of qualitative and quantitative data and an appreciation of site context.

By including non-quantitative data, namely the voice of experts familiar with the landscape context, and tying image dates to the timing of historical events such as periods of conflict and the introduction of land use regulations and controls, this research has been able to unravel some of the more subtle pathways in understanding processes of forest cover change. Previous studies have highlighted the uniqueness of different study sites when applying similar remote sensing methods alongside considerations of landscape, historic, administrative and political context (for example Cassidy et al., 2013; Fox and Vogler., 2005; Kong et al., 2019; Malila et al., 2014; Negassa et al., 2020 and Yismaw et al., 2014). This study contributes to the existing research by emphasising analysis at varying scales of geography (case studies) within a protected area to identify differences across the study site. In addition, an attempt to identify the possible causal factors of forest cover change in this research was premised on understanding localised differences in observations at the case studies.

The various management strategies and regulations put in place to limit forest access and use at Angkor have altered the spatial pattern and extent of forest cover during the time period of this research, as have less tangible factors such as the impact of civil war, tourism, and as discussed by Le Billon (2000) an often unregulated political and economic landscape. Many forests evolve as a result of ongoing management and forest resource utilisation by local communities (Fairhead \& Leach, 1996), as is the case at certain locations in the current study. However, other broader factors associated with Cambodia's political and economic transformation, as discussed in the introduction and described by Milne 


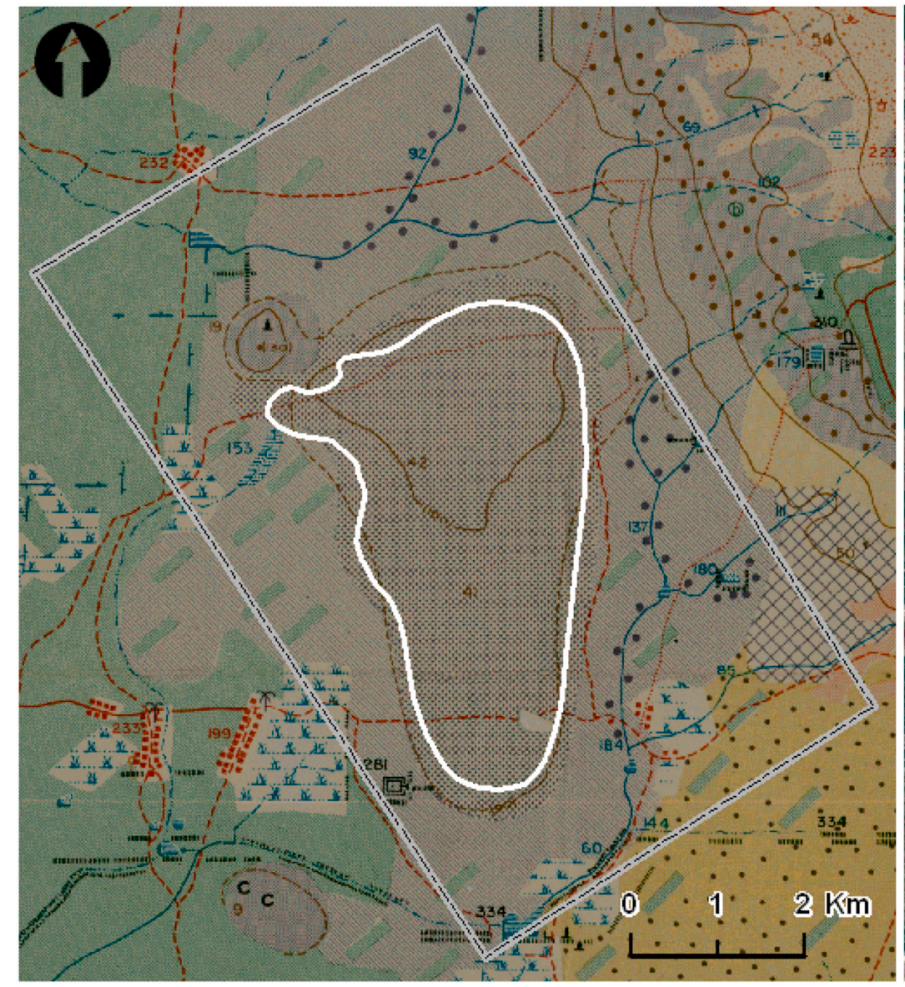

(a)

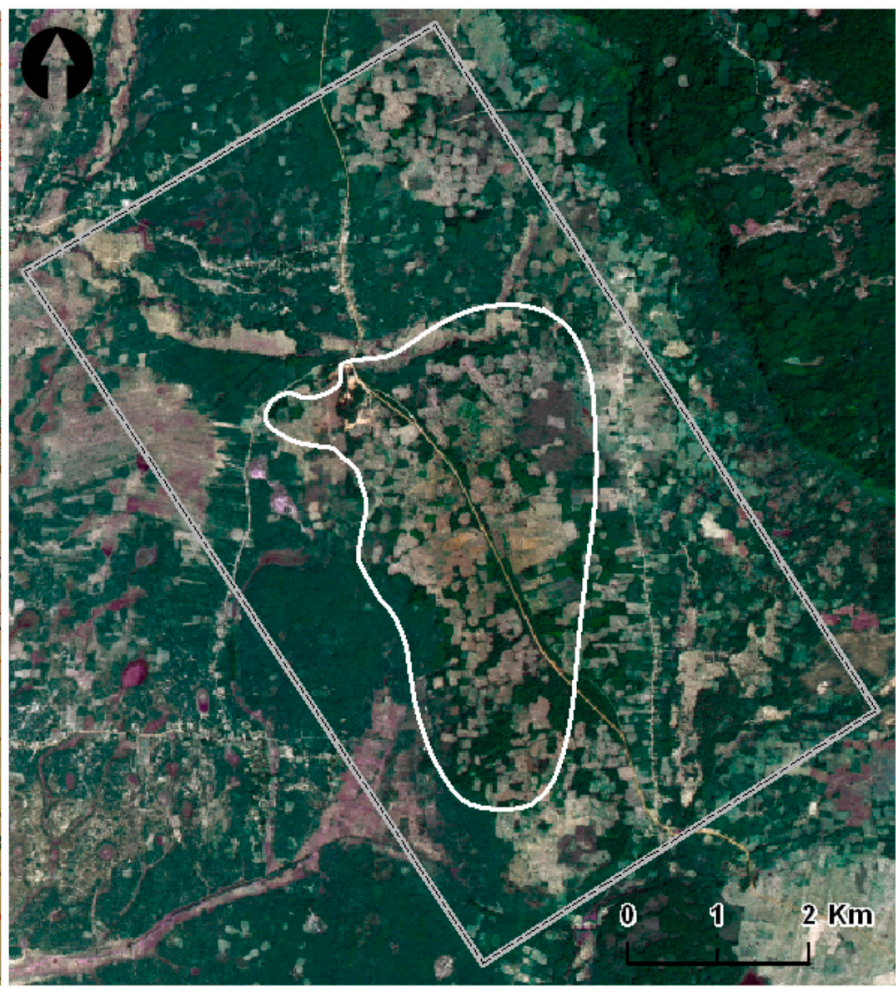

(b)

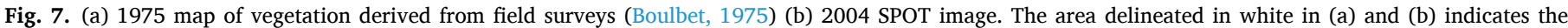

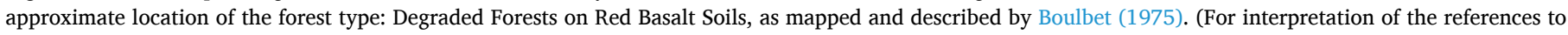
colour in this figure legend, the reader is referred to the Web version of this article.)

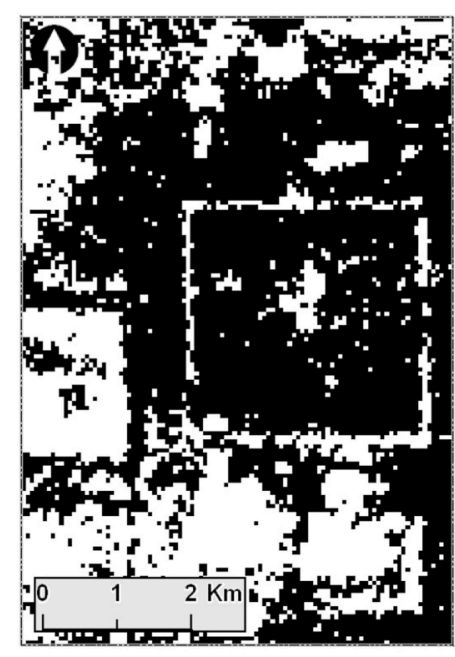

1976

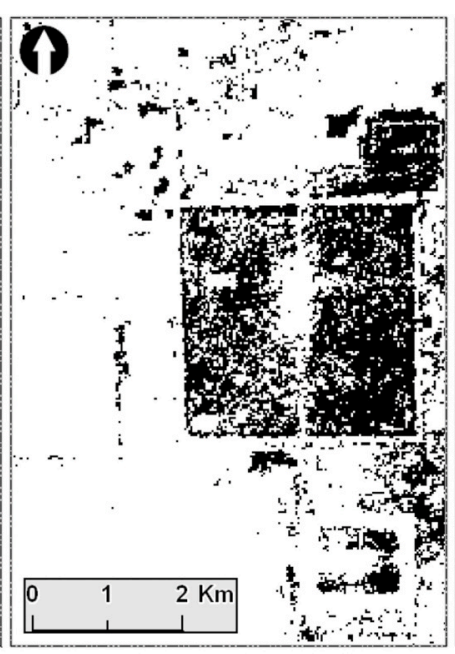

1990

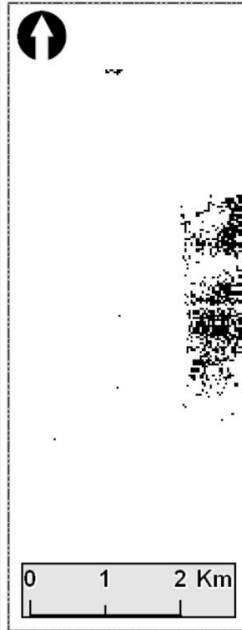

1995

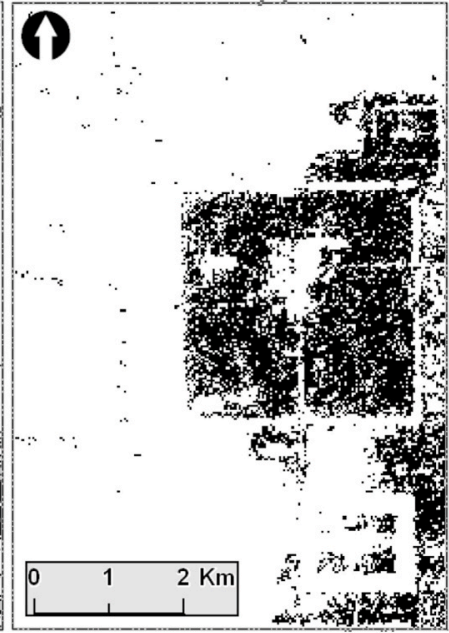

2002

Fig. 8. Areas of forest and non-forest at four different times from 1976 to 2002. Black areas indicate forest.

\& Mahanty (2015), Le Billon (1999, 2000) and Gururani and Vandergeest (2014) have also in less direct ways, impacted forest cover observable in more recent times.

As examined, the conservation and protective status of forests across Angkor (case study 2 and 3) and within Phnom Kulen (case study 1) are not uniform. Although management controls on forest use within Zones 1 and 2 provide a relatively secure protective status, those areas located outside of these two zones are less secure. Key informant interviews reveal that forest monitoring in Phnom Kulen is left largely to local people living across the site, with infrequent visits by representatives from the authority in charge. This again raises questions about challenges of resource governance and forest management, as discussed by Le Billon (2002) and Milne \& Mahanty (2015), and demonstrates the need for improved management and landscape-scale monitoring. This is achievable using the methods adopted by this research combining remotely sensed imagery in combination with ground survey and 
nuanced insight from local experts.

In light of the changing relationship between nature and society in contemporary Cambodia (Le Billon, 1999; Milne \& Mahanty, 2015), an untangling of complex ecological, socio-economic and political processes was not possible within the scope of the research. In addition, identifying forest change is somewhat constrained by the spatial resolution of the imagery, this is despite Landsat satellite imagery providing good temporal coverage while maintaining consistent spatial coverage. Applying coarse-scale image classification methods to specific locations on the ground can be problematic, a potential limitation that is acknowledged. Further, variations in the extent and quality of forest as a consequence of local land use, such as swidden agriculture and firewood collection, can occur at very fine spatial scales, often in the range of 5-10 $\mathrm{m}^{2}$, and may not be well detected using coarse scale Landsat imagery (Schmidt-Vogt et al., 2009). Lastly, although all images are near-anniversary, there was an approximate two and a half month difference between the Landsat TM 1990 and 1995 images which may have resulted in seasonal differences between the two images, potentially impacting on the comparability of the classification outputs.

The use of recent and higher resolution satellite imagery combined with more complete observational data via village-scale interviews in future research would improve the ability to detect and understand processes of change, potentially contributing to future planning and decision making on matters related to forest and World Heritage management and conservation at the site. This is despite the 'unknowns' associated with a resource that according to Le Billon (1999; 2000) is politicized and poorly governed.

\section{Declaration of competing interest}

This statement confirms I have no competing interest in this research. The contents of this paper have not been published or submitted for publication elsewhere. As the sole author I guarantee that the requirements of authorship have been met.

\section{Acknowledgements}

I wish to thank Dr Eleanor Bruce and Dr Richard Murphy from The University of Sydney for their guidance and support during this research, and an anonymous reviewer for useful comments on an earlier version of the paper. I also acknowledge the Japan International Cooperation Agency (JICA) and the Mekong River Commission (MRC), and say thanks to my Cambodian field guide and friend Mr Borey Hang.

Financial support for this research was provided by an Australian Research Council Australian Postgraduate Award (Industry) Scholarship. The research was funded from an ARC-Linkage Project: 'Living with Heritage: Integrating Time, Place and Culture for World Heritage Conservation' LP0454989. The content of this paper has not been published or submitted for publication elsewhere.

\section{References}

Ashwell, D., \& Fitzwilliams, J. (1993). Zoning and environmental management plan for Angkor: Background report on the vegetation ecology of Angkor and environs. Cambodia: Scientific and Cultural Organization (UNESCO). Unpublished report prepared by David Ashwell (International Union for Conservation of Nature) and James Fitzwilliams (CONCERN) for the United Nations Educational.

Boulbet, J. (1975, 1979). Le Phnom Kulen et sa Région: Carte et Commentaire [Phnom Kulen and its Region: Map and Commentary]. Paris: École Française d'Extrême-Orient.

Bürgi, M., Hersperger, A. M., \& Schneeberger, N. (2004). Driving forces of landscape change - current and new directions. Landscape Ecology, 19(8), 857-868.

Cassidy, L., Binford, M., Southworth, J., \& Barnes, G. (2010). Social and ecological factors and land-use land-cover diversity in two provinces in south-east Asia. Journal of Land Use Science, 5(4), 277-306.

Cassidy, L., Southworth, J., Gibbes, C., \& Binford, M. W. (2013). Beyond classifications: Combining continuous and discrete approaches to better understand land-cover change within the lower Mekong River region. Applied Geography, 39, 26-45.

Chann, S. (2019). Making place and creating frontiers: Examining land and resource struggles in Cambodian post-conflict resource landscapes. The Geographical Journal. https://doi.org/10.1111/geoj.12340.
Chazdon, R. L., Brancalion, P. H. S., Laestadius, L., Bennett-Curry, A., Buckingham, K., Kumar, C., Moll-Rocek, J., Vieira, I. C., \& Wilson, S. J. (2016). When is a forest a forest? Forest concepts and definitions in the era of forest and landscape restoration. Ambio, 45(5), 538-550.

Colson, F., Bogaert, J., Filho, A. C., Nelson, B., Pinagé, E. R., \& Ceulemans, R. (2009). The influence of forest definition on landscape fragmentation assessment in Rondônia, Brazil. Ecological Indicators, 9(6), 1163-1168.

Congalton, R. G. (1991). A review of assessing the accuracy of classifications of remotely sensed data. Remote Sensing of Environment, 37(1), 35-46.

Cope, M., \& Elwood, S. (2009). Qualitative GIS: A mixed methods approach. London: SAGE.

Curran, P. J. (1985). Principles of remote sensing. New York: Longman Scientific and Technical and John Wiley \& Sons Inc.

Davies, K. P., Murphy, R. J., \& Bruce, E. (2016). Detecting historical changes to vegetation in a Cambodian protected area using the Landsat TM and ETM + sensors. Remote Sensing of Environment, 187, 332-344.

Dy Phon, P. (2000). Dictionary of plants used in Cambodia. Phnom Penh (Published by the author).

Eav, B. B. (1970). Contribution a l'Étude de l'Ámenagement de la Reserve des Phnom Kolen et de Kohker [Contribution to the study of the management of the Phnom Kulen and Kohker Reserve]. Mémoire de Fin d'Études, Université des Science Agronomiques. Master's thesis. University of Agricultural Sciences (Phnom Penh).

Evans, D. H., Pottier, C., Fletcher, R., Hensley, S., Tapley, I., Milne, A., \& Barbetti, M. (2007). A comprehensive Archaeological map of the world's largest preindustrial settlement complex at Angkor, Cambodia. Proceedings of the National Academy of Sciences of the United States of America, 104(36), 14277-14282.

Fairhead, J., \& Leach, M. (1996). Misreading the African landscape: Society and ecology in a forest-savanna mosaic. England: Cambridge University Press.

Fairhead, J., \& Leach, M. (1998). Reframing deforestation: Global analysis and local realities: Studies in west Africa. England: Routledge.

FAO. (2000). FRA 2000 on definitions of forest and forest change. Forest Resources Assessment Working Paper 033. Rome. Available at: http://www.fao.org/docrep/ 006/ad665e/ad665e00.htm. (Accessed 3 May 2017).

Foody, G. M. (2002). Status of land cover classification accuracy assessment. Remote Sensing of Environment, 80(1), 185-201.

Foody, G. M., \& Arora, M. K. (1996). Incorporating mixed pixels in the training, allocation and testing stages of supervised classifications. Pattern Recognition Letters, 17(13), 1389-1398.

Foody, G. M., Palubinska, G., Lucas, R. M., Curran, P. J., \& Honzak, M. (1996). Identifying terrestrial carbon sinks: Classification of successional stages in regenerating tropical forest from Landsat TM data. Remote Sensing of Environment, 55 (3), 205-216.

Fox, J., Rindfuss, R. R., Walsh, S. J., \& Mishra, V. (2003). People and the environment: Approaches for linking household and community surveys to remote sensing and GIS. Boston; London: Kluwer Academic Publishers.

Fox, J., \& Vogler, J. (2005). Land-use and land-cover change in montane Mainland Southeast Asia. Environmental Management, 36, 394-403.

Freeman, M. (2004). Cambodia. London: Reaktion Books.

Gaughan, A. E., Binford, M. W., \& Southworth, J. (2009). Tourism, forest conversion, and land transformations in the Angkor basin, Cambodia. Applied Geography, 29(2), 212-223.

Gillespie, J. (2009). Protecting World heritage: Regulating ownership and land use at Angkor Archaeological park, Cambodia. International Journal of Heritage Studies, 15 (4), 338-354.

Giteau, M. (1976). The civilization of Angkor. New York: Rizzoli.

Gururani, S., \& Vandergeest, P. (2014). Introduction: New frontiers of ecological knowledge: Co-producing knowledge and governance in Asia. Special section: Ecological knowledge in Asia. Conservation and Society, 12(4), 343-351.

Hadjimitsis, D. G., Papadavid, G., Agapiou, A., Themistocleous, K., Hadjimitsis, M. G., Retalis, A., Michaelides, S., Chrysoulakis, N., Toulios, L., \& Clayton, C. R. I. (2010). Atmospheric correction for satellite remotely sensed data intended for agricultural applications: Impact on vegetation indices. Natural Hazards and Earth System Sciences, 10, 89-95.

Hagesteijn, R. (1987). The Angkor state: Rise, fall and in between. In H. J. M. Claessen, \& P. Van de Velde (Eds.), Early state dynamics. Papers presented at the conference on the early state and after, held august 17-19, 1983 (pp. 154-169). Leiden, The Netherlands: University of Montreal.

Haque, M. I., \& Basak, R. (2017). Land cover change detection using GIS and remote sensing techniques: A spatio-temporal study on Tanguar haor, Sunamganj, Bangladesh. The Egyptian Journal of Remote Sensing and Space Science, 20(2), 251-263. https://doi.org/10.1016/j.ejrs.2016.12.003.

Hay, I. (2005). Qualitative research methods in human geography. Melbourne: Oxford University Press.

Hubbard, C. (2002). Seeing the Community for the trees: Assessing locally-developed sustainability Indicators for the Angkor community forest project, Cambodia. Master's thesis. Vancouver, Canada: Simon Fraser University.

Hughes, C. (2009). Reconstructing legitimate political authority through elections? In S. Turnell, \& M. Lilja (Eds.), Beyond Democracy in Cambodia: Political reconstruction in a post-conflict society (pp. 31-69). Copenhagen: Nordic Institute of Asian Studies Press.

ITTO. (2005). Status of tropical forest management 2005. International tropical timber organisation. Available at: https://www.itto.int/direct/topics/topics.../to pics $i d=12370000 \& n o=1 \& \_$lang $=j$ a. (Accessed 20 September 2015).

Jiang, H. (2003). Stories remote sensing images can tell: Integrating remote sensing analysis with ethnographic research in the study of cultural landscapes. Human Ecology, 31(2), 215-232. 
Kahya, O., Bayram, B., \& Reis, S. (2008). Land cover classification with an expert system approach using Landsat ETM imagery: A case study of Trabzon. Environmental Monitoring and Assessment, 160(1-4), 431-438.

Kiernan, B. (2007). Conflict and change in Cambodia. London: New York: Routledge.

Kim Phat, N., Ouk, S., Uozumi, Y., \& Ueki, T. (2001). A case study of the current situation for forest concessions in Cambodia - constraints and prospects. Journal of Forest Planning, 7(2), 59-67.

Kintz, D., Young, K., \& Crews-Meyer, K. (2006). Implications of land use/land cover change in the buffer zone of a national park in the tropical Andes. Environmental Management, 38, 238-252.

Kong, R., Diepart, J., Castella, J., Lestrelin, G., Tivet, F., Belmain, E., \& Bégué, A. (2019) Understanding the drivers of deforestation and agricultural transformations in the Northwestern uplands of Cambodia. Applied Geography, 102(1), 84-98.

Kummu, M. (2009). Water management in Angkor: Human impacts on hydrology and sediment transportation. Journal of Environmental Management, 90(3), 1413-1421.

Le Billon, P. (1999). Power is Consuming the forest: The political Ecology of Conflict and Reconstruction in Cambodia. PhD dissertation. University of Oxford.

Le Billon, P. (2000). The political ecology of transition in Cambodia 1989-1999: War, peace and forest exploitation. Development and Change, 31(4), 785-805. https://doi. org/10.1111/1467-7660.00177.

Le Billon, P. (2001). The political ecology of war: Natural resources and armed conflict. Political Geography, 20(5), 561-584. https://doi.org/10.1016/S0962-6298(01) 00015-4.

Le Billon, P. (2002). Logging in Muddy waters: The politics of forest exploitation in Cambodia. Critical Asian Studies, 34(4), 563-586. https://doi.org/10.1080/ 1467271022000035938 .

Legris, P., \& Blasco, F. (1972). La végétation naturelle. In "Notice de la Carte du Cambodge". (Carté International du Tapis Végétal et des Conditions Écologiques au Cambodge, 1/1,000,000.) (Vol. 11, pp. 1-238). Trav. Sect. Scient. Techn. Inst. Fr. Pondichéry.

Lemaistre, A., \& Cavalier, S. (2002). Analyses and management prospects of the international Angkor programme. Museum International, 54(1-2), 117-125.

Lillesand, T. M., Kiefer, R. W., \& Chipman, J. W. (2015). Remote sensing and image interpretation (7th ed.). New York: John Wiley \& Sons Inc.

MacDicken, K. G. (2015). Global forest resources assessment 2015: What, why and how? Forest Ecology and Management, 352, 3-8.

Malila, W. A., Metzier, M. D., Rice, D. P., \& Crist, E. P. (1984). Characterization of LANDSAT-4 MSS and TM digital image data. IEEE Transactions on Geoscience and Remote Sensing, 22, 177-191. https://doi.org/10.1109/TGRS.1984.350593.

The political ecology of Cambodia's transformation. In Milne, S., \& Mahanty, S. (Eds.), Conservation and development in Cambodia: Exploring frontiers of change in nature, state, and society, (pp. 19-45). (2015) (pp. 19-45). Abingdon, Oxon: Routledge.

Negassa, M. D., Mallie, D. T., \& Gemeda, D. O. (2020). Forest cover change detection using geographic information systems and remote sensing techniques: A spatiotemporal study on komto protected forest priority area, east wollega zone, Ethiopia. Environmental Systems Research, 9(1). https://doi.org/10.1186/s40068-020-0163-z.

Peluso, N. L., \& Lund, C. (2011). New frontiers of land control: Introduction. Journal of Peasant Studies, 38(4), 667-681. https://doi.org/10.1080/00220388.2010.485633.

Philip, L. J. (1998). Combining quantitative and qualitative approaches to social research in human geography - an impossible mixture? Environment \& Planning A, 30(2), 261-276.

Plieninger, T., Levers, C., Mantel, M., Costa, A., Schaich, H., \& Kuemmerle, T. (2015). Patterns and drivers of scattered tree loss in agricultural landscapes: Orchard Meadows in Germany (1968-2009). PloS One, 10(5).

Redmond, J., Gschwantner, T., Riedel, T., Alberdi, I., Vidal, C., Bosela, M., Fischer, C., Hernández, L., Kucera, M., Kuliesis, A., Tomter, S. M., Westman, M., \& Lanz, A.
(2016). Comparison of wood resource assessment in national forest inventories. In C. Vidal, I. Alberdi, L. Hernández, \& J. J. Redmond (Eds.), National forest inventories assessment of wood availability and use (pp. 25-53). Switzerland: Springer International Publishing.

Richards, J. A., \& Jia, X. (2013). Remote sensing digital image analysis: An introduction (4th ed.). Berlin Heidelberg: Springer-Verlag.

Rogan, J., Franklin, J., \& Roberts, D. A. (2002). A comparison of methods for monitoring multitemporal vegetation change using Thematic Mapper imagery. Remote Sensing of Environment, (80), 143-156. https://doi.org/10.1016/S0034-4257(01)00296-6.

Rollet, B. (1972). La végétation du Cambodge. Bois et Forets des Tropiques, 144-146, $3-20$.

Royal Government of Cambodia. (1994). Royal decree establishing protected cultural zones in the Siem reap/Angkor region and guidelines for their management. Phnom Penh: Royal Government of Cambodia.

Royal Government of Cambodia. (2001). Land law, kram NS/RKM/0801/14 dated August 30 2001. Phnom Penh: Royal Government of Cambodia.

Royal Government of Cambodia. (2002). Law on forestry, KRAM NS/RKM/0802/016 dated july 30 2002. Phnom Penh: Royal Government of Cambodia.

Rundel, P. W. (1999). Forest Habitats and Flora in Lao PDR, Cambodia and vietnam. Hanoi, vietnam: World wide fund for nature.

Schmidt-Vogt, D., Leisz, S., Mertz, O., Heinimann, A., Thiha, T., Messerli, P., Epprecht, M., Cu, P. V., Chi, V. K., Hardiono, M., \& Dao, T. (2009). An assessment of trends in the extent of swidden in Southeast Asia. Human Ecology, 37(3), 269-280.

Seto, K. C., Woodcock, C., Song, C., Huang, X., Lu, J., \& Kaufmann, R. (2002). Monitoring land-use change in the pearl river delta using Landsat TM. International Journal of Remote Sensing, 23(10), 1985-2004.

Singh, M., Evans, D. H., Tan, B. S., \& Nin, C. S. (2015). Mapping and characterizing selected canopy tree species at the Angkor World heritage site in Cambodia using Aerial data. PloS One, 10(4). https://doi.org/10.1371/journal.pone.0154548.

Sloan, S., \& Sayer, J. A. (2015). Forest Resources Assessment of 2015 shows positive global trends but forest loss and degradation persist in poor tropical countries. Forest Ecology and Management, 352(7), 134-145.

Song, C., Woodcock, C. E., Seto, K. C., Lenney, M. P., \& Macomber, S. A. (2001). Classification and change detection using Landsat TM data: When and how to correct atmospheric effects? Remote Sensing of Environment, 75(2), 230-244.

Stibig, H. J., Achard, F., \& Fritz, S. (2004). A new forest cover map of continental Southeast Asia derived from SPOT-VEGETATION satellite imagery. Applied Vegetation Science, 7(2), 153-162.

Thapa, R. B., \& Murayama, Y. (2009). Urban mapping, accuracy, \& image classification: A comparison of multiple approaches in Tsukuba city, Japan. Applied Geography, 29, $135-144$.

UNESCO. (1994). Final report of the zoning and environmental management plan for Angkor (ZEMP). Paris: UNESCO.

Verplanke, J., McCall, M. K., Uberhuaga, C., Rambaldi, G., \& Haklay, M. (2016). A shared perspective for PGIS and VGI. The Cartographic Journal, 53(4), 308-317.

Wager, J. (1995). Environmental planning for a World heritage site: Case study of Angkor, Cambodia. Journal of Environmental Planning and Management, 38(3), 419-434.

Yismaw, A., Gedif, B., Addisu, S., \& Zewudu, F. (2014). Forest cover change detection using remote sensing and GIS in Banja district, Amhara region, Ethiopia. International Journal of Environmental Monitoring and Analysis, 2(6), 354-360. https://doi.org/10.11648/j.ijema.20140206.19.

Zimmermann, J., \& Clements, T. J. (2004). Preliminary Study of the species Composition of a Gradient of forest Types in southern Mondulkiri, Cambodia. Phnom Penh: Wildlife Conservation Society - Cambodia Program. 